UDK 631.313.02:531

\title{
SUBSTANTIATION OF MAIN PARAMETERS OF SIZE-SIZED SERIES OF AGRICULTURAL ENERGY SOLUTIONS
}

\author{
G. V. Shkarovsky \\ National University of Life and Environmental Sciences of Ukraine. Ukraine. \\ Speciality of article: 133 - industry engineering. \\ Corresponding authors: grishkar@i.ua.
}

Article history: Received - October 2019, Accepted-January 2020.

Bibl. 10, fig. 0, tabl. 5.

\begin{abstract}
The solution of the problems of the agroindustrial complex depends to a large extent on the provision of highly efficient mobile energy facilities, the availability of which is provided by a standard size series. The construction of the size range is based on the main parameters that should most fully characterize the technical, operational and technological capabilities of the product and have greater stability than the auxiliary parameters. It has been established that there are at least three approaches to the justification of the standard size series of power tools: according to the nominal tractive effort. On power of the installed engine, by annual load. In accordance with this, we can distinguish three main parameters for which there have been attempts to justify the size series, namely: nominal tractive effort, Installed engine power and annual load. The named parameters are disjointed because their rationale was taken in consideration of the various problems that need to be solved. The foregoing circumstances make it difficult to apply economically viable approaches to designing, manufacturing and ensuring the effective use of energy resources, which has led to the search for other, or additional, main parameters for constructing a standard size range of mobile power tools. The studies were carried out by analyzing the influence of the investigated parameters on the characteristics of energy facilities and their stability within the limits of the possible classes of the standard size series. As a result of the studies carried out to justify and improve the size of a number of mobile agricultural energy products, it has been established that, in order to provide the most informative information about mobile energy facilities, which is laid down in the main parameters of their size range, the latter can be represented as a multiparametric one, the main parameters of which are appropriate to take the nominal traction Power, engine power and level of versatility. These parameters will give an idea of the traction capabilities of the energy source, its energy potential and the availability of technical means for implementing traction capabilities and installed capacity.
\end{abstract}

Key words: mobile power facility, size range, main parameter, nominal tractive effort, installed engine power, level of versatility.

\section{Introduction}

The introduction of technological progress in agroindustrial production stimulated the tractor-building enterprises to significantly expand the standard-size series of products, the adequate elements of which very often differ in the values of similar estimated parameters. So, for example, according to the data of the catalog $[1,2,3$, 4], energy sources of the structural mass of $5000-5500 \mathrm{~kg}$ of firms Renault, Deutz-Fahr, Fendt are equipped with engines with a capacity of $63-88 \mathrm{~kW}$, and energy facilities of Massey Ferguson, Case IH, John Deere, MTZ, New Holland in The same class of structural mass can be equipped with engines up to $119 \mathrm{~kW}$. In the later catalogs, this increase in capacity is already observed in the energy resources of the previously named firms.

\section{Formulation of problem}

The foregoing is evidence of the existence of certain difficulties with the method of justifying the standard series of mobile power means (MPM) based on the main parameters that should most fully characterize the technical, operational and technological capabilities of the product and have greater stability than auxiliary parameters [5, 6].

\section{Analysis of recent research results}

The rationale for the standard size row of tractors was previously carried out according to different main parameters. So in 1940, D. A. Chudakov suggested taking traction for a parameter to determine the class of the tractor. In the perspective type of tractors of 1946 in the Soviet Union, the main parameter was the engine power [7]. The increase in engine power required to provide higher operating speeds had little effect on the tractor's traction parameters, Therefore, at that time, the nominal traction force was accepted as the main parameter for justifying a standard row of tractors for a long time. The basis for the determination is the traction force, in which the coefficient of utilization of the clutch, and 
accordingly, the trailing of the tractor, does not exceed the preset values [7]:

$$
P_{K P . \mathrm{H}}=\varphi_{K P} \times G_{1},
$$

where: $P_{K P . H}-$ is the nominal pulling force,

$\varphi_{K P}-$ coefficient of use of the coupling weight,

$G_{1}$ - coupling weight of the tractor.

This indicator was more stable when modernizing machines, including increasing their capacity.

With the development of the construction of tractors and agricultural machinery, their recoil systems and energy intake, crop cultivation technologies, etc., the tractor is also seen as a mobile energy device capable of delivering energy through power take-off systems. First of all, this applies to harvesting machines. For harvesting self-propelled chassis (their feature is the ability to be released from the structure of an assembly), in which the bulk of the power is used through the power take-off shaft (PTO), the engine power rating can be retained [7].

Attempts to develop a standard size series of MPM for the installed engine power are described in $[8,9,10$, $11,12]$. The criteria for justifying the power levels in these works were the possibilities of providing economic performance indicators, mainly traction and traction drive units, under various conditions while ensuring the optimum level of engine loading. It should be noted that the above-mentioned papers show different power levels of power-driven engines. This fact indicates the absence of unified scientifically grounded approaches to the graduation of energy resources by installed engine power.

In [12], a classification of energy resources by annual load is proposed, which allows to predict the possible economic efficiency of the energy source. The drawbacks of this work are both the lack of a scientifically grounded methodology for classifying power resources to groups by the installed engine power and annual load, and the focus on cleaning machines specialized and created based on the released selfpropelled chassis, which, in our opinion, complicates the forecast calculations of farm parks.

In $[13,14]$ the approximate power levels of MPM engines for agricultural purposes are presented both in the general case and within each of the existing traction classes, but nothing is said about using the established graduation as a standard range for energy resources.

Thus, as a result of the analysis, it has been established that there are at least three approaches to the justification of the MPM standard series: according to the nominal traction force, On power of the installed engine, By annual load. According to this, we can distinguish three main parameters for which there were attempts to justify the size series, namely: nominal tractive effort, Installed engine power and annual load. In addition, in later works (not shown here), the necessity of using several parameters or their derivatives for the characterization of the MPM size series (tractive effort and engine power, energy saturation, etc.) is substantiated. The foregoing circumstances make it difficult to apply economically viable approaches to designing, manufacturing and ensuring the effective use of energy resources, which encourages the search for other, or additional, main parameters for constructing a one- or multi-parametric MPM-type series.

\section{Purpose of research}

In connection with the foregoing, the purpose of this paper is to justify a list of the main parameters for characterizing a range of mobile agricultural energy products.

\section{Results of research}

The studies were carried out by analyzing the influence of individual parameters on the characteristics of energy facilities and their stability within the limits of the possible classes of the standard size series. In this connection, it became necessary to conduct an analysis of the activities of the world's leading tractor-building enterprises on the characteristics of the energy facilities they create on the plane of the parameters, the mass of the structural energy, mass of the total energy, the installed engine power and the price.

The existing technological processes of growing crops [15] envisage the implementation of predominantly traction operations, which indicates an indisputable relevance for the characterization of the standard size range of the parameter "nominal tractive effort", which is determined by the mass characteristics of the machine. The analysis of the design parameters and the total mass of energy means that the vast majority of machines due to ballasting can significantly change the traction performance up to the possibility of transition to other traction classes determined by the standard GOST 2702186 [16]. Thus, for example, the Fendt Favorit-822 energy product, which has a structural mass of $8100 \mathrm{~kg}$, belongs to the traction class 3 with a nominal pulling force of $30 \mathrm{kN}$, according to the graduation standard [16], and under the condition of its ballasting, according to the catalog data [1] to class 6 with a nominal pulling force of $60 \mathrm{kN}$.

And in this connection, it may be interesting that each hauling class of a standard range of energy facilities, built according to the nominal tractive effort, is characterized by the limits of the operational mass of the energy resources entering into it.

To establish this fact, the research was carried out by analyzing the procedure for the formation of the standard MPM series of standard size series and analyzing the characteristics of energy resources of the world's leading tractor-building enterprises on the parameters plane, the operating mass of the energy source and the nominal tractive effort.

In addition, despite the fact that mobile power means must provide for the implementation of traction, traction and drive and drive operations, the study of the boundaries of the change in the operational mass within each traction class was carried out with the following considerations.

According to the technique of the standard [16], the operating mass is determined using the dependence:

$$
P_{\text {ГК.Н }}=A \times m_{e P_{\Gamma К . H}},
$$

where: $P_{\text {ГК.Н }}-$ is the nominal pulling force of the energy facility, $\mathrm{kN}$,

$A$ - is a coefficient that is set depending on the type of energy source (the coefficient $A$ is to be taken as: - 
$3.24 \times 10-3-$ for energy resources with an operating weight of up to $2,600 \mathrm{~kg}-3,73 \times 10-3$ - for four and three-wheeled energy facilities with two driving wheels (4K2 and $3 \mathrm{~K} 2$ ) with an operating weight of more than $2,600 \mathrm{~kg}-3,92 \times 10-3-$ for energy facilities with a wheel formula $4 \mathrm{~K} 4$ and an operating weight of more than $2,600 \mathrm{~kg}-4.9 \times 10-3$ - for caterpillar power facilities),

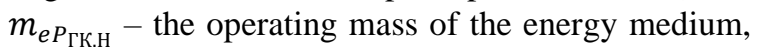
at which the nominal traction force of the level under study is reached, $\mathrm{kg}$.

Table 1. Limits of variation of operational masses of wheeled power facilities of the current standard size range.

\begin{tabular}{|c|c|c|c|c|c|c|}
\hline \multirow{2}{*}{$\begin{array}{c}\text { Traction class } \\
\text { of energy } \\
\text { resources }\end{array}$} & \multicolumn{2}{|c|}{$\begin{array}{l}\text { Limits of variation of nominal } \\
\text { tractive effort, } \mathrm{kN}\end{array}$} & \multicolumn{2}{|c|}{$\begin{array}{l}\text { Operational mass of energy } \\
\text { means } *, \mathrm{~kg}\end{array}$} & \multicolumn{2}{|c|}{ Change in operating weight } \\
\hline & from & to & $\begin{array}{l}\text { the lower } \\
\text { limit }\end{array}$ & $\begin{array}{l}\text { the upper } \\
\text { limit }\end{array}$ & in ... times & by ...\% \\
\hline 0,2 & 1,8 & 5,4 & $\geq 555,6$ & $<1666,7$ & 3,00 & 200,0 \\
\hline 0,6 & 5,4 & 8,1 & $\geq 1666,7$ & $<2500,0$ & 1,50 & 50,0 \\
\hline 0,9 & 8,1 & 12,6 & $\geq 2500,0$ & $<3214,3$ & 1,29 & 28,6 \\
\hline 1,4 & 12,6 & 18,0 & $\geq 3214,3$ & $<4591,8$ & 1,43 & 42,8 \\
\hline 2 & 18,0 & 27,0 & $\geq 4591,8$ & $<6887,7$ & 1,50 & 50,0 \\
\hline 3 & 27,0 & 36,0 & $\geq 6887,7$ & $<9183,7$ & 1,33 & 33,3 \\
\hline 4 & 36,0 & 45,0 & $\geq 9183,7$ & $<11479,6$ & 1,25 & 25,0 \\
\hline 5 & 45,0 & 54,0 & $\geq 11479,6$ & $<13775,5$ & 1,20 & 20,0 \\
\hline 6 & 54,0 & 72,0 & $\geq 13775,5$ & $<18367,3$ & 1,33 & 33,3 \\
\hline 8 & 72,0 & 108,0 & $\geq 18367,3$ & $<27551,0$ & 1,50 & 50,0 \\
\hline
\end{tabular}

*) The change in the value of the coefficient $\boldsymbol{A}$ provided in the explanations for the dependence (2) in accordance with the received level of the operational mass was carried out in the calculations at the first achievement of the above indicator value of $2600 \mathrm{~kg}$ and was subsequently assumed equal to $3.92 \times 10^{-3}$, The bulk of wheeled energy is produced in an all-wheel drive version, or one that can easily be transformed into a four-wheel drive.

The above dependence (2) is a consequence of the above dependence (1).

Proceeding from the above, in order to provide the traction efforts of wheeled energy facilities of various classes regulated by the standard size range [16], their operating masses can vary within the following limits Table 1.

In Table 1 shows the limits of variation of the operating masses of energy resources for each traction class ensuring the implementation of the corresponding tractive effort. The data of Table. 1 indicate that even in the middle of the traction classes provided by the standard, the operating masses of energy resources can vary significantly. So, for class 0.2 , the operating masses of energy resources can differ by three times, or by $200 \%$ compared to the lower limit of the operational mass, typical for the energy resources of this traction class. A similar picture is observed for energy resources of other traction classes, but with quantitative indicators, which are characterized by somewhat smaller values. Thus, the increase in the operational masses of energy classes 0.6 , $0.9 .1 .4,2,3,4,5,6$ and 8 inside the traction classes is envisaged in $1.2 \ldots 1.5$ times, or $20 \ldots 50 \%$. The size range is organized in such a way that its points cover energy means of various designs, different manufacturers, and hence different masses. And only due to the boundaries of the variation of the operational mass of energy resources (see Table 1, columns 4 and 5) provided by the standard, it is possible to classify such energy assets and assign them to the appropriate traction class.

It should be noted that the actual operating mass of energy resources operating in farms is significantly higher than its lower limit is indicated in Table. 1. So the class 1.4 tractor "Belarus-1005" has an operational weight of $4025 \mathrm{~kg}$ with a minimum for this class of $3214.3 \mathrm{~kg}$, a tractor of the same class "Belarus - 82" has an operating weight of $3900 \mathrm{~kg}$, and UMZ- 6AKM - $3895 \mathrm{~kg}$. The tractor of class $3 \mathrm{KhTZ}-121$ has an operational weight of $8,200 \mathrm{~kg}$ with the lower limit for this class equal to $6887.7 \mathrm{~kg}$. A similar situation is typical for cars that represent the vast majority of traction classes. In this case, if we also take into account the possibility of ballasting of such energy resources, at least within the limits named in, then the maximum operational mass of tractors of classes $0.6,0.9,1.4,3,4,5$ Will exceed the level of the upper limits of the operational masses for the energy resources of the named classes and such machines will be transferred to higher traction classes. For example, a tractor of class 3 KhTZ-121, as already mentioned above, has an operating weight of $8,200 \mathrm{~kg}$. The ballasting of this tractor at a rate of $23 \%$ will lead to an increase in its total operating weight to the level of $10086 \mathrm{~kg}$, which is typical already for traction class 4 vehicles (see Table 1). Tractors class 0.2 , with ballasting within $23 \%$, do not go to higher traction classes because the standard provides for them a wide range of variation in the operational mass, and class 2 tractors, such as LTZ-155, "Belarus1221" Have an initial operating weight, which, with ballasting by $23 \%$, does not lead to a change in the traction class of the machines. Another situation with the class 5 energy equipment. So according to the catalog, the tractors $\mathrm{K}-744-1$ and $\mathrm{K}-701 \mathrm{M}$ belong to the traction class 5 , their operational masses have the value $15830 \mathrm{~kg}$ and $14570 \mathrm{~kg}$ respectively, which according to Table. 1 allows them to be attributed to the traction class 6 even without ballasting. The foregoing allows us to draw certain conclusions, namely: $a$ ) theoretically - about certain inaccuracies in the dependence $(2), b$ ) in practical terms the lack of effective ways to implement the available operating mass of energy.

Based on the foregoing, it can be argued that, in practice, the range of variation of the operating mass of 
the energy source, conditioned by the standard, is, for the most part, of a reference nature. In such a case, it is important that the energy asset, in its characteristics, clearly correspond to the traction class to which it is assigned, and its operating mass achieved in any way, including ballasting, can vary both within the limits of the energy standard specified in the standard for this class, not excluding the transition to higher traction classes.

Thus, the limits of variation of the operating masses of power-supply devices of the type-size series, which are described by the values 555.6 - $27551.0 \mathrm{~kg}$. When determining the position of the energy facility in a standard size, it should be ensured that its characteristics meet the requirements for machines of a specific traction class, and the operational weight, taking into account ballasting, could vary both within the limits of the energy facilities stipulated by regulatory documents for this class, Not excluding the transition to higher traction classes.

This fact suggests that the "nominal tractive effort" index can not be used as the main parameter for a oneparameter type series because the principle of parameter stability is violated.

Used by foreign experts, as the main parameter, the "installed engine power" parameter is an indicator of the efficiency of the energy medium and is also indispensable for the consumer. The data in the catalog [1] indicate that the power of the engines installed on the energy sources (the analysis was carried out for standard tractors with a capacity of over $24 \mathrm{~kW}$, such as those that are basic for carrying out the main set of works in diversified agricultural enterprises) varies widely. So MTZ represents power facilities with engine power from 24 to $96 \mathrm{~kW}$, Case IH - from 38 to $280 \mathrm{~kW}$, Fendt - from 37 to $199 \mathrm{~kW}$, John Deere - from 39 to $342 \mathrm{~kW}$, etc. About the possibility of using the installed engine power The following should be noted as the main parameter of the MPM standard size series. The overwhelming majority of tractor-building firms in a standardized series declared for the production of energy resources has machines with the same power of the installed engine. Thus, Fendt produces three brands of energy products with an engine power of $63 \mathrm{~kW}$ with a structural mass of 3850, 4190 and $5070 \mathrm{~kg}$, which, according to the procedure of [16], allows them to be assigned to traction classes of $1.4,1.4$ and 2 respectively, and taking into account the possible ballasting - to classes 2, 3 and 3 respectively. The analyzed characteristics belong, respectively, to the energy facilities of Fendt Farmer 308C, Fendt Farmer 308CA and Fendt Farmer 409 Vario [1]. In addition, we should also give an example of the KhTZ-120 tractors, which had an engine with a discretely adjustable power of 88 and $107 \mathrm{~kW}$, where a higher power level is recommended for operation in the unit with machines that have a drive from the tractor PTO.

Table 2. Brief specifications of John Deere and Fendt energy tools with engine power up to $60 \mathrm{~kW}$.

\begin{tabular}{|c|c|c|c|c|c|c|}
\hline \multirow{3}{*}{ Indicator } & \multirow{3}{*}{$\begin{array}{l}\text { Units of } \\
\text { measure }\end{array}$} & \multicolumn{5}{|c|}{ Brand of equipment } \\
\hline & & \multicolumn{3}{|c|}{ John Deere } & \multicolumn{2}{|c|}{ Fendt } \\
\hline & & 5510 & $\begin{array}{c}\text { 6110A } \\
\text { SE }\end{array}$ & $6120 \mathrm{~A}$ & $\begin{array}{c}\text { Farmer } \\
\text { 307C }\end{array}$ & F 370 GT \\
\hline 1 Engine power & $\mathrm{kW}$ & 59 & 59 & 59 & 55 & 55 \\
\hline 2 Engine displacement & $\mathrm{cm}^{3}$ & 4530 & 4530 & 4530 & 3190 & 4086 \\
\hline 3 Rated engine speed & $\min ^{-1}$ & 2400 & 2300 & 2300 & 2300 & 2400 \\
\hline 4 Engine torque & $\mathrm{H} \times \mathrm{m}$ & 301 & 327 & 328 & 296 & 263 \\
\hline 3 Torque reserve & $\%$ & 28 & 34 & 33.5 & 30 & 16 \\
\hline $\begin{array}{l}6 \text { Number of gears: } \\
\text { Forward motion } \\
\text { Reverse gear }\end{array}$ & $\begin{array}{l}\text { pcs. } \\
\text { pcs. }\end{array}$ & $\begin{array}{l}24 \\
24 \\
\end{array}$ & $\begin{array}{l}16 \\
16 \\
\end{array}$ & $\begin{array}{l}24 \\
24 \\
\end{array}$ & $\begin{array}{c}21 \\
6 \\
\end{array}$ & $\begin{array}{c}21 \\
6 \\
\end{array}$ \\
\hline $\begin{array}{l}7 \text { Travel speed: } \\
\text { The maximum } \\
\text { Minimal }\end{array}$ & $\begin{array}{l}\mathrm{Km} / \mathrm{hr} \\
\mathrm{Km} / \mathrm{hr}\end{array}$ & $\begin{array}{l}40 \\
0,5 \\
\end{array}$ & $\begin{array}{l}40 \\
0,8 \\
\end{array}$ & $\begin{array}{l}42 \\
1,0 \\
\end{array}$ & $\begin{array}{l}40 \\
0,7 \\
\end{array}$ & $\begin{array}{l}40 \\
0,4 \\
\end{array}$ \\
\hline 8 Number of PTO & pes. & 2 & 2 & 2 & 2 & 2 \\
\hline 9 Number of speeds PTO & pes. & 2 & 3 & 3 & 3 & 3 \\
\hline $\begin{array}{l}10 \text { Payload of attached devices: } \\
\text { Posterior } \\
\text { Front }\end{array}$ & $\begin{array}{l}\mathrm{Kg} \\
\mathrm{Kg}\end{array}$ & $\begin{array}{c}\ldots *) \\
2000 \\
\end{array}$ & $\begin{array}{c}3990 \\
\ldots\end{array}$ & $\begin{array}{l}4520 \\
3500 \\
\end{array}$ & $\begin{array}{l}4980 \\
2945 \\
\end{array}$ & $\begin{array}{l}3210 \\
2250 \\
\end{array}$ \\
\hline 11 Hydraulic system pump capacity & $1 / \mathrm{min}$ & $43,1+18.2$ & 54 & $60 / 96$ & 70 & $41+36$ \\
\hline 12 Hydraulic system pump type & - & Gear & Gear & Axial & Gear & Gear \\
\hline 13 Presence of a mounting platform & - & - & - & - & - & + \\
\hline 14 Weight of payload ballast & $\mathrm{Kg}$ & 2075 & 3066 & 2650 & 2200 & 2410 \\
\hline 15 Construction weight & $\mathrm{Kg}$ & 2725 & 3934 & 4350 & 3800 & 3590 \\
\hline 16 Price & DM & 29700 & 37000 & 41800 & 36100 & 38900 \\
\hline
\end{tabular}

\section{*) There is no data on the indicator}

Based on the foregoing, it can be concluded that the two named parameters "nominal tractive effort" and "installed engine power" are inadequate characteristics of a standard range of mobile power facilities.
Taking into account that "... the optimization of parametric (standardized) series has an important ... value." Optimum selected parametric series satisfy the requirements ... in products of different species at the lowest total costs "[17], it is necessary to justify at least 
one Or several main parameters that would allow itself, or together with others (for example, the two above) to obtain the most complete information about the energy source.

The characteristics given in the catalog [1] show that the price of energy for leading manufacturers in the world varies widely, even if they have engines of the same power. To establish the reasons for this fact, we examined more detailed characteristics of energy facilities that have engines of the same power. The studies were carried out using the characteristics of John Deere and Fendt energy facilities with engines up to $60 \mathrm{~kW}$ (Table 2).

The data of Table 2 show that the John Deere energy used almost the same engine with a capacity of $4530 \mathrm{~cm}^{3}$, which could not significantly change the manufacturer's pricing policy. The main differences in the technical characteristics were such indicators as the number of gears, the number of PTO speeds, the load capacity of mounted devices, the characteristics of the hydraulic system, the mass of the ballast and the structural mass. Each of these indicators is designed to ensure more efficient use of energy in various operations with a large number of machines and tools. So the number of gears determines the ability to ensure efficient use with machines and tools that are characterized by different levels of engine energy consumption, i.e. Allows you to more efficiently load the engine. The number of speeds of the power take-off shaft also provides more efficient loading of the engine, the lifting capacity of the attached devices limits the weight of the attached machines. The characteristics of the hydraulic system determine the possibility and efficiency of the energy output of the engine through the hydraulic system. In particular, the installation of an axial-type pump allows adapting the hydrosystem of the energy source to the hydraulic systems of machines with different characteristics of the flow of working fluid. Mass characteristics also determine the traction of energy.

So, for example, if we compare the energy of the John Deere 5510 and John Deere 6120, we can say that the latter significantly benefits in terms of the lifting capacity of the mounted devices, the characteristics of the hydraulic system and the tractive characteristics provided by the structural mass and ballast, which significantly influenced the increase in value within $12100 \mathrm{DM}$.

A similar picture is observed for Fendt's energy facilities. However, it should be noted that their cost is significantly higher than the energy facilities of John Deere, which is explained by the significantly better indicators of the lifting capacity of the mounted devices and the availability of a cargo platform for the Fendt F 370 GT. The foregoing is confirmed in the higher classes of capacity of energy resources.

The increase in the cost of Fendt's 74 and $154 \mathrm{~kW}$ power equipment is primarily due to the use of a hydrostatic transmission, which allows for any speed in the $0-50 \mathrm{~km} / \mathrm{h}$ range and, therefore, to load the engine more efficiently, even when compared to the Fendt Favorit 822, Which is completely reversible and has 44 transmissions (Table 3).

Table 3. Brief technical characteristics of Fendt energy facilities with engine power of 74 and $154 \mathrm{~kW}$.

\begin{tabular}{|c|c|c|c|c|c|}
\hline \multirow[b]{2}{*}{ Indicator } & \multirow[b]{2}{*}{$\begin{array}{l}\text { Unit of } \\
\text { measure }\end{array}$} & \multicolumn{4}{|c|}{ Energy brand } \\
\hline & & $\begin{array}{c}\text { Fendt } \\
\text { Farmer } \\
309\end{array}$ & $\begin{array}{c}\text { Fendt } \\
\text { Farmer } \\
410 \text { Vario }\end{array}$ & $\begin{array}{c}\text { Fendt } \\
\text { Favorit } \\
822\end{array}$ & $\begin{array}{c}\text { Fendt } \\
\text { Favorit } \\
920 \text { Vario }\end{array}$ \\
\hline 1 Engine power & $\mathrm{kW}$ & 74 & 74 & 154 & 154 \\
\hline 2 Engine displacement & $\mathrm{cm}^{3}$ & 3190 & 3800 & 6870 & 6870 \\
\hline 3 Rated engine speed & $\min ^{-1}$ & 2300 & 2100 & 2200 & 2150 \\
\hline 4 Engine torque & $\mathrm{N} \times \mathrm{m}$ & 390 & 437 & 896 & 960 \\
\hline 5 Engine torque reserve & $\%$ & 30 & 35 & 34 & 40 \\
\hline $\begin{array}{l}6 \text { Number of gears: } \\
\text { Forward motion } \\
\text { Reverse gear }\end{array}$ & $\begin{array}{l}\text { pes. } \\
\text { pes. }\end{array}$ & $\begin{array}{c}21 \\
6 \\
\end{array}$ & $\begin{array}{l}\text { Hydrostat } \\
\text { Hydrostat }\end{array}$ & $\begin{array}{l}44 \\
44 \\
\end{array}$ & $\begin{array}{l}\text { Hydrostat } \\
\text { Hydrostat }\end{array}$ \\
\hline $\begin{array}{l}7 \text { Travel speed: } \\
\text { The maximum } \\
\text { Minimal }\end{array}$ & $\begin{array}{l}\mathrm{Km} / \mathrm{h} \\
\mathrm{Km} / \mathrm{h}\end{array}$ & $\begin{array}{l}40 \\
0,7 \\
\end{array}$ & $\begin{array}{c}50 \\
\left.0,0^{*}\right) \\
\end{array}$ & $\begin{array}{l}50 \\
0,2 \\
\end{array}$ & $\begin{array}{l}50 \\
0,0 \\
\end{array}$ \\
\hline 8 Number of PTO & pcs & 2 & 2 & 2 & 2 \\
\hline 9 Number of speeds PTO & pcs & 3 & 3 & 2 & 2 \\
\hline $\begin{array}{l}10 \text { Hoisting capacity of attachments: } \\
\text { Posterior } \\
\text { Front }\end{array}$ & $\begin{array}{l}\mathrm{Kg} \\
\mathrm{Kg}\end{array}$ & $\begin{array}{l}4980 \\
2945\end{array}$ & $\begin{array}{l}6440 \\
2920\end{array}$ & $\begin{array}{l}9000 \\
5000\end{array}$ & $\begin{array}{l}9000 \\
5000\end{array}$ \\
\hline 11 Hydraulic system pump performance & $1 / \mathrm{min}$. & 70 & 75 & 102 & 112 \\
\hline 12 Hydraulic system pump type & - & Gear & Axial & Axial & Axial \\
\hline 13 Presence of an installed site & - & - & - & - & - \\
\hline 14 Weight of payload ballast & $\mathrm{Kg}$ & 3280 & 3790 & 5900 & 5250 \\
\hline 15 Constructional weight & $\mathrm{Kg}$ & 4220 & 5210 & 8100 & 8750 \\
\hline 16 Price & $\mathrm{DM}$ & 46500 & 63200 & 99200 & 110000 \\
\hline
\end{tabular}

*) 0,0 - the phenomenon exists, but in values less than those that can be expressed by the digital digits used in the table 
Table 4. The value of the coefficient of universality of the construction of tractors involved in the performance of various technological processes of growing and harvesting crops according to the technological maps of 2004

\begin{tabular}{|c|c|c|c|c|c|c|c|c|c|c|}
\hline \multirow[b]{2}{*}{ Culture } & \multicolumn{10}{|c|}{ Brand tractor } \\
\hline & $\begin{array}{c}\text { KhTZ- } \\
170\end{array}$ & $\begin{array}{c}\text { T- } \\
150 \mathrm{~K}\end{array}$ & $\begin{array}{c}\mathrm{T}- \\
150\end{array}$ & $\begin{array}{c}\text { KhTZ- } \\
120\end{array}$ & $\begin{array}{c}\mathrm{T}- \\
70 \mathrm{~S}\end{array}$ & $\begin{array}{l}\text { UMZ- } \\
\text { 6AKL }\end{array}$ & $\begin{array}{c}\text { UMZ- } \\
80\end{array}$ & $\begin{array}{l}\text { MTZ- } \\
80 / 82\end{array}$ & $\mathrm{~T}-25$ & $\begin{array}{c}\mathrm{T}- \\
16 \mathrm{MG}\end{array}$ \\
\hline 1. Perennial Herbs & - & - & 0,14 & - & - & 0,13 & - & 0,20 & 0,14 & - \\
\hline 2. Potatoes & - & 0,17 & 0,15 & - & - & - & - & 0,17 & - & - \\
\hline 3. Corn for grain & 0,15 & 0,15 & 0,15 & - & - & 0,10 & - & 0,15 & - & - \\
\hline 4. Corn for silage & - & 0,15 & 0,15 & - & - & 0,09 & - & 0,15 & - & 0,09 \\
\hline 5. Winter Wheat & 0,15 & 0,15 & 0,15 & - & - & 0,09 & - & 0,13 & 0,06 & - \\
\hline 6. Winter Rye & - & 0,15 & 0,15 & - & - & 0,10 & - & - & 0,06 & 0,09 \\
\hline 7. Wheat Jara & 0,15 & 0,14 & 0,15 & - & - & 0,09 & - & 0,11 & - & - \\
\hline 8. Sunflower & - & 0,17 & 0,15 & 0,14 & - & 0,10 & 0,20 & - & 0,06 & 0,09 \\
\hline 9. Sugar Beet & - & 0,15 & 0,15 & - & 0,17 & 0,10 & - & 0,14 & - & - \\
\hline 10. Barley & - & 0,15 & 0,15 & - & - & 0,12 & - & - & 0,06 & 0,09 \\
\hline
\end{tabular}

If we analyze the indicators of Tables 2 and 3 , especially from number 6 to 15, then taking into account the results of the studies described in $[18,19,20]$, it can be asserted that these indicators determine the level of universality of the energy facility and, ultimately, influence its cost. In this case, it can be argued that the level of universality of energy resources can perform the function of the main parameter of a standard size series.

In addition, depending on the availability of machines for the creation of machine and tractor units based on this or that energy facility of the size range, which will be determined by the financial condition of the state as a whole and of the individual agricultural producer in particular, this parameter will allow to optimize the size range for economic indicators.

This suggests that the parameter "level of universality of energy resources" will allow the process of optimization of the standard MPM series from the plane of solving static problems to the plane of solving dynamic problems, which is more reliable and promising.

In this case, it is worth paying more attention to the method of obtaining such an indicator as «the level of universality of $K_{\mathrm{yK}}$ energy resources». In particular, studies on the dynamics of the variation in the design universality coefficient [21] carried out in the technological processes of growing and harvesting cereals, in particular winter wheat, winter rye, spring wheat, spring and winter barley, carried out according to the technological maps of 1984-2001 made it possible to establish that the estimated The values of the coefficient of universality of the design of certain brands of tractors involved in the performance of technological processes differ little both in the context of years (only 6-7\%) and in $\mathrm{p}$ The number of cultivated crops (no more than 14-18\%), which can be explained by the use of technologies from the times of the collective farm and state farm system and the machine complexes designed for their implementation. Several other values of the universality coefficient obtained during the research of technologies of recent years [15] - Table 4.

However, it should be borne in mind that a size range of products is created for its consumer. This means that the consumer should get the maximum information about the elements of the size series already from the very row, so the use of the parameter "level of universality of the energy facility" alone is not sufficient. In such conditions, it is advisable to use three parameters at the current stage when justifying a standard MES series: the nominal tractive effort, Engine power, level of versatility. These parameters will give an idea of the traction capabilities of the energy source, its energy potential and the availability of technical means for their implementation.

The results of the studies are presented in Table. 4 indicate that in recent years there have been some changes in the technology of growing crops and in the technical means for their implementation. So, in particular the technology of growing sunflower provides for the use of tractors of grade 1.4 of the UMZ brand, while the UMZ$6 \mathrm{AKL}$ tractors should provide a level of versatility of 0.10 , and tractors of the UMZ-80 type should provide a level of versatility of 0.20 , that is, two Times higher, which can be explained by certain progress in the design of tractors UMZ and the presence of more sophisticated machine complexes that allow this progress to be more fully realized. In confirmation of the above, it should be noted that in the previous crop rotation [21], sunflower is also present, and it was intended to use UMZ-6AKL tractors for its cultivation, but their planned level of universality should not exceed 0.13 . Some analogies of such a plan could be made for tractors MTZ-80 and MTZ82 in the technological process of growing perennial grasses, but for them the information presented in the tables is less complete than in tractors UMZ.

Taking into account the foregoing, the output parameters for constructing a geometric series of levels of universality of MPM should be taken in terms of indicators characteristic for tractors UMZ, since class 1.4 in which these tractors are included is the most widespread and most provided with machine complexes, and hence the most researched that for others Classes and brands of tractors for today is only desirable. Under such conditions, this allows us to take the value 0.10 as

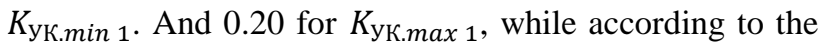
condition of [18] $K_{\mathrm{УК}}$ should not exceed unity.

After the calculations carried out by the method described in [13], it is established that the geometric series of levels of universality of the MPM is characterized by the denominator $g_{\mathrm{yK}}=1.778$ and includes 5 levels, namely: $0.10,0.18,0.32,0.56$ and 1.00 . The received level of versatility is a requirement for the overall design and layout of the machine. 
So, for example, if it is necessary to provide a machine with a level of universality of 0.56 and lower, then it is possible to implement it with the help of all three construction and layout schemes, and if it is a level of universality of 1.00 , then this can be realized only by the construction of a self-propelled chassis (cm See [18]).

It is logical to assume that the level of development of technological modules for aggregation with MPM and the most energy facilities will not be so rapid to realize all the declared level of universality. Therefore, it is advisable to assume that the increase in the level of universality of energy facilities will be carried out together with the development of technological modules to them at a slower pace due to a change in the equipment of a certain level of universality.

Table 5. Interaction of basic and intermediate levels of Universal Mobile power means (MPM)

\begin{tabular}{|c|c|c|c|c|c|c|c|c|c|c|}
\hline The level of universality & \multicolumn{10}{|c|}{ The value of the level of universality } \\
\hline Basic & 0,10 & 0,18 & & & & & & & & \\
\hline Intermediate & - & 0,10 & 0,20 & 0,30 & 0,40 & 0,50 & 0,60 & 0,70 & 0,80 & 0,90 \\
\hline
\end{tabular}

An additional analysis of [21] and Table 2 showed that this can be achieved if we introduce a number of intermediate levels of universality, while it is expedient to use an arithmetic progression with a difference $\mathrm{d}=0.10$ as an intermediate series. Then a number of intermediate levels of universality will be 9 orienting levels, namely: $0.10,0.20,0.30,0.40,0.50,0.60,0.70,0.80,0.90$.

Given that the base level is the maximum possible for a particular machine design, the interaction of the basic and intermediate levels of universality can be represented as follows (Table 5).

As shown by the data placed in Table. 5, the greatest number of intermediate levels is characteristic of the highest index among the basic levels of universality, which is understandable, since this level can be provided only by the constructive-layout scheme of the selfpropelled chassis, which is intended for use as a multipurpose power facility. The practice of tractor construction shows that the classical and integral design and layout schemes of MPM may have slightly different universality [18], however, in our opinion, in order to avoid excessive costs, consumers of such equipment would be sufficient to make energy means of classical and integral assemblies With a basic level of universality not higher than 0.56, ensuring its full implementation of the corresponding machine complexes.

The results of additional studies have made it possible to establish that in the technological processes a maximum of $24 . . .46 \%$ of the potential built into the design of domestic power facilities is realized. In this way, the UMZ-8240 type energy-generating equipment with the construction design value of the design universality coefficient at the level of 0.43 in the operating technological processes can maximally realize the level of 0.20 , KhTZ -16131, with the available coefficient equal to 0.57 , and $\mathrm{T}-16 \mathrm{MG}$, respectively 0.38 and 0.09 .

This situation can be explained by many reasons. First of all, these are stagnant phenomena in the development of technological processes, the lack of modern technical solutions in the creation of machine and tractor units, machines and tools designed to maximize the use of potential capabilities of energy resources, which negatively affects the production costs of agricultural enterprises and underscores the need to clarify the current technological processes in crop production and Complexes of machines for their implementation, including MPM.
The justification of the basic levels of universality in the development of MPM will allow solving the question of justifying the design of the machine at the design stage, providing for the maximum possible configuration and layout to achieve the required level of universality. And already the bundling in deliveries to the consumer (by installing or not installing the ordered units) to regulate the level of universality and, accordingly, the price of energy.

\section{Conclusions}

1. As a result of the conducted researches it is established that in order to provide the most informative information about mobile power means, which is placed in the main parameters of their standard series, the latter is expediently represented by a multiparameter, the main parameters of which are to take the nominal tractive effort, the installed engine power and the level of universality.

2. The main direction of further research on this issue is the substantiation of the multi-parametric, standard-size range of mobile agricultural energy products.

\section{References}

1. Pogorily L. V. (2004). Modern problems of agricultural mechanics and engineering when creating a new generation of agricultural machinery. Machinery AIC. №1-2. 6-7.

2. Dubrovin V., Krasovski E., Rogovskiy I. (2011). Complex machines measure the effectiveness of the crop. MOTROL. Commission of Motorization and Energetics in Agriculture. 13B. 20-24.

3. Antoschenkov R. (2013). Theoretical and research of the dynamic model of the wheeled tractor $30 \mathrm{kN}$. MOTROL. Commission for Motorization and Energetics in Agriculture. 15/7. 170-175.

4. Shkarivsky G. V. (2014). Estimation of the influence of the constructive-layout schemes of energy resources on the aggregation of units on their basis. MOTROL. Commission of Motorization and Energetics in Agriculture. Vol. 16. No 3. 165-171.

5. Shkarivsky G. V. (2004). Research performance versatility tractors engaged in the performance of core processes. Interdepartmental thematic scientific collection 
"Mechanization and Electrification of Agriculture". Glevaha, NSC "IMESH". Vol. 88. 78-85.

6. Saenko, A. V. (2016). Universal stand for definition of coefficient of friction and coefficient of rolling resistance of the tractor. Bulletin of Sumy national agrarian University. Series: mechanization and automation of production processes. Vol. 10 (2). 15-19.

7. Russini, A., Schlosser, J. F., Farias, M. S. (2018). Estimation of the traction power of agricultural tractors from dynamometric tests. Cienc. Rural vol. 48 no. 4 Santa Maria, Epub Apr. 16, 2018. DOI: 10.1590/0103$8478 \mathrm{cr} 20170532$.

8. Henchoz, Y., Crivelli, G., Borrani, F., Millet, G. (2010). A new method to measure rolling resistance in treadmill cycling J Sports Sci. Aug; 28(10):1043-6. DOI: 10.1080/02640414.2010.498483.

9. Kutkov, G. M. (2004). Tractors and cars. Theory and technological properties. Moscow. Colossus. 504.

10. Grebnev, V. P., Polivaev, A. S., Vorokhobin, A. B. (2011). Tractors and cars. Theory and performance properties. Moscow. KNORUS. 264.

\section{Список літератури}

1.Погорілий Л. В. Сучасні проблеми сільськогосподарської механіки та машинобудування при створенні сільськогосподарської техніки нового покоління. Техніка АПК. 2004. №1-2. С. 6-7.

2.Dubrovin V., Krasovski E., Rogovskiy I. Complex machines measure the effectiveness of the crop. MOTROL. Commission of Motorization and Energetics in Agriculture. 13B. 2011. P. 20-24.

3.Antoschenkov $R$. Theoretical and research of the dynamic model of the wheeled tractor $30 \mathrm{kN}$. MOTROL. Commission for Motorization and Energetics in Agriculture. 15/7. 2013. P. 170-175.

4.Shkarivsky G. V. Estimation of the influence of the constructive-layout schemes of energy resources on the aggregation of units on their basis. MOTROL. Commission of Motorization and Energetics in Agriculture. Vol. 16. No 3. 2014. P. 165-171.

5.Шкарівський $\quad$. $\quad$ B. $\quad$ Багатофункціональні трактори, що займаються виконанням основних процесів. Міжвідомчий тематичний науковий збірник «Механізація та електрифікація сільського господарства». Глеваха, ННЦ "ІМЕСГ". 2004. Вип. 88. C. $78-85$.

6.Кутьков Г. М. Тракторы и автомобили. Теория и технологические свойства. Москва. КолосС, 2004. $504 \mathrm{c}$.

7.Гребнёв В. П., Поливаев О. И., Ворохобин А. В. Тракторы и автомобили. Теория и эксплуатационные свойства. Москва. КНОРУС. 2011. 264 с.

8.Саснко A. B. Універсальний стенд для визначення коефіцієнта зчеплення та коефіцієнта опору коченню трактора. Вісник Сумського національного аграрного університету. Серія: механізація та автоматизація виробничих процесів. 2016. Вип. 10(2). С. 15-19.

9.Russini A., Schlosser J. F., Farias M. S. Estimation of the traction power of agricultural tractors from dynamometric tests. Cienc. Rural vol. 48 no. 4 Santa
Maria, 2018. Epub Apr. 16, 2018. DOI: 10.1590/0103$8478 \mathrm{cr} 20170532$.

10. Henchoz Y., Crivelli G., Borrani F., Millet G. A new method to measure rolling resistance in treadmill cycling J Sports Sci. 2010 Aug; 28(10):1043-6. DOI: 10.1080/02640414.2010.498483.

\section{ОБГРУНТУВАННЯ ГОЛОВНИХ ПАРАМЕТРІВ \\ ТИПОРОЗМІРНОГО РЯДУ ЕНЕРГОЗАСОБІВ СІЛЬСЬКОГОСПОДАРСЬКОГО ПРИЗНАЧЕННЯ Г. В. Шкарівський \\ Анотація. Вирішення проблем} агропромислового комплексу у великій мірі залежить від забезпеченості високоефективними мобільними енергетичними засобами, наявність яких передбачається типорозмір ним поруч. Побудова типорозмірного ряду грунтується на головних параметрах, які повинні найбільш повно характеризувати технічні, експлуатаційні i технологічні можливості вироби і володіти більшою стабільністю, ніж допоміжні параметри. Встановлено, що існує щонайменше три підходи до обгрунтування типорозмірний рядів енергосредств: по номінальному тяговому зусиллю, по потужності встановленого двигуна, за річного завантаження. Відповідно з цим можна виділити три головних параметра, за яким існували спроби обгрунтування типорозмірного рядів, a саме: номінальне тягове зусилля, потужність встановленого двигуна і річна завантаження. Названі параметри розрізнені оскільки їх обгрунтування велося враховуючи різні проблеми, які необхідно вирішити. Викладені обставини ускладнюють застосування економічно доцільних підходів до проектування, виготовлення і забезпечення ефективного використання енергозасобів, що призвело до пошуку інших, або додаткових головних параметрів для побудови типорозмірного ряду мобільних енергетичних засобів. Дослідження проводилися шляхом аналізу впливу досліджуваних параметрів на характеристики енергозасобів i ïx стабільності в межах можливих класів типорозмірного ряду. В результаті проведених досліджень по обгрунтуванню та вдосконалення типорозмірного ряду мобільних енергетичних засобів сільськогосподарського призначення встановлено, що 3 метою забезпечення найбільшої інформативності про мобільних енергетичних засобах, яка закладена в головних параметрах їх типорозмірного ряду останній може бути представлений як багатопараметричний, головними параметрами якого доцільно прийняти номінальне тягове зусилля, потужність встановленого двигуна і рівень універсальності. Названі параметри дадуть уявлення про тягові можливості енергозасобу, його енергетичному потенціалі і наявності технічних засобів для реалізації тягових можливостей i встановленої потужності.

Ключові слова: мобільний енергетичний засіб, типорозмірний ряд, головний параметр, номінальне тягове зусилля, потужність встановленого двигуна, рівень універсальності. 
ОБОСНОВАНИЕ ГЛАВНЫХ ПАРАМЕТРОВ

ТИПОРАЗМЕРНОГО РЯДА ЭНЕРГОСРЕДСТВ

СЕЛЬСКОХОЗЯЙСТВЕННОГО НАЗНАЧЕНИЯ

Г. В. Шкаровский

Аннотация. Решение проблем агропромышленного комплекса в большой степени зависит от обеспеченности высокоэффективными мобильными энергетическими средствами, наличие которых предусматривается типоразмерным рядом. Построение типоразмерного ряда основывается на главных параметрах, которые должны наиболее полно характеризовать технические, эксплуатационные и технологические возможности изделия и обладать большей стабильностью, чем вспомогательные параметры. Установлено, что существует по меньшей мере три подхода к обоснованию типоразмерный рядов енергосредств: по номинальному тяговому усилию, по мощности установленного двигателя, по годовой загрузке. В соответствии с этим можно выделить три главных параметра, по которым существовали попытки обоснования типоразмерного рядов, а именно: номинальное тяговое усилие, мощность установленного двигателя и годовая загрузка. Названные параметры разрозненные поскольку их обоснования велось учитывая различные проблемы, которые необходимо решить. Изложенные обстоятельства затрудняют применение экономически целесообразных подходов к проектированию, изготовлению и обеспечению эффективного использования энергосредств, что привело к поиску других, или дополнительных главных параметров для построения типоразмерного ряда мобильных энергетических средств. Исследования проводились путем анализа влияния исследуемых параметров на характеристики энергосредств и их стабильности в пределах возможных классов типоразмерного ряда. В результате проведенных исследований по обоснованию и совершенствования типоразмерного ряда мобильных энергетических средств сельскохозяйственного назначения установлено, что с целью обеспечения наибольшей информативности о мобильных энергетических средствах, которая заложена в главных параметрах их типоразмерного ряда последний может быть представлен как многопараметрический, главными параметрами которого целесообразно принять номинальное тяговое усилия, мощность установленного двигателя и уровень универсальности. Названные параметры дадут представление о тяговые возможности энергосредства, его энергетическом потенциале и наличии технических средств для реализации тяговых возможностей и установленной мощности.

Ключевые слова: мобильное энергетическое средство, типоразмерный ряд, главный параметр, номинальное тяговое усилие, мощность установленного двигателя, уровень универсальности.

G. V. Shkarovsky ORCID 0000-0002-2381-6534. 
